\title{
Farmers' Agro-climatological Knowledge of Changes in Precipitation and Temperature Extremes in Semi-arid Nakasongola
}

\author{
Owoyesigire, Brian ${ }^{1,2}$ (Corresponding author), \\ ${ }^{1}$ Department of Agricultural Production, School of Agricultural Sciences, College of Agricultural and \\ Environmental Sciences (CAES), Makerere University, P. O. Box 7062 Kampala, Uganda \\ ${ }^{2}$ Buginyanya Zonal Agricultural Research and Development Institute (BugiZARDI),Uganda \\ E-mail: bowoyesigire@caes.mak.ac.ug, bowoyesigire@gmail.com \\ Denis Mpairwe \\ Department of Agricultural Production, School of Agricultural Sciences, College of Agricultural and \\ Environmental Sciences (CAES), Makerere University, P. O. Box 7062 Kampala, Uganda
}

\begin{abstract}
Understanding agro-climatological knowledge of farmers to climate extremes provides useful information in developing appropriate adaptation strategies critical for enhancing resilience of agricultural systems to climate change. This study was conducted to establish farmers' agro-climatological knowledge and perceptions to trends of climate extremes in semi-arid Nakasongola district. Climate extremes were derived by analyzing rainfall and temperature data sets from 1970 to 2013 using RClimdex software. Data to establish farmer's knowledge were collected through face to face household interviews and analyzed using descriptive statistics by SPSS. Annual total precipitation (PRCPTOT) index showed increasing non significant trends $(\mathrm{P}>0.05)$. Heavy precipitation days $(\mathrm{R} 10 \mathrm{~mm})$ showed weak positive non significant increasing trend $(\mathrm{P}<0.05)$. Consecutive wet days $(\mathrm{CWDs})$ were decreasing $(\mathrm{P}<0.05)$ while consecutive dry days (CDDs) were significantly increasing. Percentage hot days were positively increasing while warm nights revealed a declining trend. Farmers' perceived changes in rainfall and temperature extremes compared well with the observed climatological trends. CDDs and heavy precipitation days were the most perceived extremes. Key adaptation strategies included; fencing of grazeable land, use of drought tolerant pasture species, utilization of crop residues and pasture conservation, water harvesting and change of grazing time. Limited access to climate information and insecure land ownership rights were key barriers constraining adaptation. Therefore policies that ensure secure land ownership rights while improving farmers' access to early warning information on climate events can effectively facilitate adaptation to climate change.
\end{abstract}

Key words: Trends, precipitation, temperature, extremes and climate change

DOI: $10.7176 / \mathrm{JNSR} / 11-20-05$

Publication date:October $31^{\text {st }} 2020$

\section{Introduction}

Climate change will continue to stress and increase the vulnerability of agricultural systems especially those in semi-arid regions in supporting sustainable livelihoods (IPCC, 2007). The cattle corridor in Uganda is characterized as semi-arid and is considered among the most fragile regions in the country (NEMA, 2008). Nakasongola district lies in the cattle corridor of Uganda where livestock production is the main agricultural activity that sustains livelihoods. Most common livestock species kept include cattle, goats, and sheep. These livestock species depend chiefly on grazing natural pastures in the rangelands. Availability of pastures and water resources in the rangelands of the cattle corridor is directly influenced by the amount of rainfall recieved and the surrounding ambient temperatures (MLWE, 2003). Climate change has affected the frequency of climate extremes (Owoyesigire et al., 2016) such as heavy precipitation days and consquently the rainfall patterns in Nakasongola district are rapidly changing. Donat et al.(2013) reported that changes in rainfall and temperature extremes are among the key indicators of climate change. Moreover, Majaliwa et al. (2015) affirmed that weather and climate are very important as they influence various aspects of daily life including water resources, food security, transport, tourism and health. Climate change will affect all dimensions of food security through reduced availability of water and increased environmental temperatures (Sridharan et al., 2019; Beddington, et al. 2011). However, CCSP (2008) observes that changes in extreme climatic events result in severe socio-economic impacts which can have both positive and negative effects. Most systems have adopted to their historical range of events of extremes implying that the majority of events outside the desired and torelable range quite often have negative impacts to society. 
Reducing negative impacts of climate change which are a result of changing extremes events can be achieved through enhanced adaptation (Kurukulasuriya and Rosenthal, 2003). Adaptation to climate change takes on many definitions (Thornton et al. 2008; Burton et al. 2005). However, IPCC (2001) defines adaptation to climate change as an adjustment in natural or human systems in response to actual or expected climatic stimuli or their effects, which moderates harm or exploits beneficial opportunities. Thornton et al. (2007) argues that adaptation can be influenced by management of resources at household level. Extreme events drive changes in natural and human systems much more than average climate (Peterson et al. 2008). For example, most organisms and life processes can always adapt to changes in climate means. However, changes in climate extremes usually result into serious devastating impacts. Climate extremes are unusual weather events in their occurrence which always lie in the upper or lower ten percentile of the distribution and have destructive potential like hurricanes, tornadoes, hailstorms, very heavy rainfall and heat waves for long period of time (CCSP, 2008). In Uganda, extreme climatic events such as extreme rainfall events have led to widespread damage to livelihoods as they always result into serious floods thus damaging infrastructure, displacement and destruction of livelihood assets. For example in 2010, the Teso sub-region was hit by floods which destroyed food crops and consequently led to increased food insecurity (KCCA, 2015). Studies on climate extremes generate information which is vital for stakeholders in making policy and management decisions for better adaptation to climate change (Manton et al. 2000; Donat \& Alexander, 2012). For example Alex et al (2019) reported that rainfall extremes will continue in the future and are likely to impact natural ecosystems as well as agricultural and societal infrastructure in Eastern Uganda. Although, Manton et al. (2000) reports that fewer studies have examined trends in climate extremes, studies elsewhere on changes in temperature and precipitation extremes have generated information vital for adaptation processes (Alex et al., 2019; Anguilar et al. 2009). However, information concerning how farmers perceive and respond to changes in climate extremes in Uganda is not yet well established. Yet, such information is necessary in developing appropriate adaptation strategies to impacts resulting from climate change and increased variability. This study was therefore conducted to establish farmers agro-climatological knowledge and perceptions to changes in trends of rainfall and temperature extremes in the cattle corridor of Uganda using Nakasongola district as an example.

\section{Materials and methods}

\subsection{Description of the study area}

The study was conducted in Nakasongola district (Figure 1) which is located in the central region of Uganda about $114 \mathrm{~km}$ along Bombo- Gulu highway north of capital Kampala. It's located on the equator at latitude $0^{0} 55 \mathrm{~N}$ to $1^{0}$ $40 \mathrm{~N}$ and longitude $31 \mathrm{E} 55 \mathrm{E}$ and $3250 \mathrm{E}$. Nakasongola district forms part of the cattle corridor' which is an area that runs from the southwest-Rwanda boarder to the Sudan/Somalia/Kenya boarder in the Northeastern direction. The vegetation in Nakasongola district is dominantly open savannah woodland comprising of Combretum terminalis, Acacia brevispica, Canthium lactescens, Grevia mollis, Teclea nobilis and Vernonia brachycalyx with tall grasses. The soils in Nakasongola district are relatively homogeneous and dominated by strongly weathered soils with high sesquioxide content (Haplic Ferralsols). Fluvisols and Dystric Fluvisols formed from undifferentiated and unconsolidated sediments on 0-2\% slope around Lake Kyoga and Kwania also exist. Livestock production is main livelihood activity (Nakasongola District State of Environment Report, 2004). Most swamps and rivers in Nakasongola are seasonal; groundwater potential is limited, with small recharge rates. Surface storage reservoirs (valley tanks and dams) often receive insufficient inflow or have too little storage capacity due to siltation and consequently agricultural yields are low due to insufficient availability of water (Mpairwe et al. 2008). 


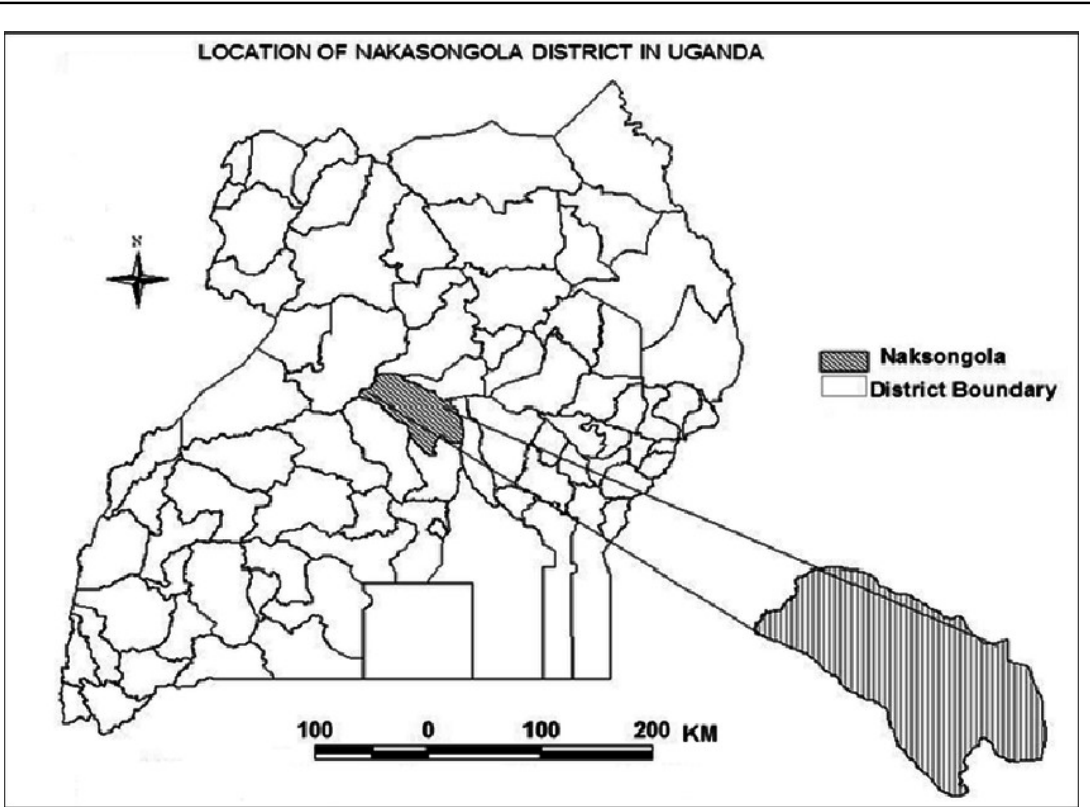

Figure 1: A map of Uganda showing location of Nakasongola district

\subsection{Data collection and analysis}

Daily rainfall and temperature (maximum and minimum) data of Soroti weather station from 1970 to 2013 were used. Data was obtained from the National Meteorological Authority (NMA). The NMA runs a net work of weather stations across the country. There are a number of weather stations in Nakasongola district which included Kakooge and Nakasongola among others. However, we could not use data sets from Kakooge and Nakasongola because they had a lot of missing values. During political insurgencies that occurred in the region in 1970s and 1980s hardly any rainfall and temperature data was collected for Kakooge and Nakasongola stations. We therefore used rainfall and temperature data sets from Soroti weather station since Nakasongola district falls in the same climatological zone (Basalirwa, 1995) and had no missing values. Data was checked to ensure no outliers and tested for homogeneity using "RHtestV3" software as in Wang and Feng (2009) to ensure quality data sets. After homogeneity tests, data was then subjected to time series analysis using RClimdex following procedures as in Zang and Feng (2004). Details of procedures in analysis of extremes are available at the ETCCDI website. RClimdex software produces 27 indices however, in this study only six precipitation and temperature extreme indices were used since they were the only indices that could be easily perceived by the farming communities (Table. 1).

Data to establish farmers' knowledge and perceptions on changes in rainfall and temperature extreme events were collected through face to face household interviews using a pre-tested semi-structured questionnaire. The questionnaires were designed to capture information such as: (i) observed changes in heavy rainfall and wet days (ii) severity of dry spells (ii) changes in environmental temperatures during day and nights (iv) impacts arising from changes in very heavy rainfall and drought events (v) possible adaptation strategies to ensure increased productivity and (vi) barriers/challenges constraining adaptation strategies among others. Households to participate in the survey were randomly selected after consultations with the existing extension and district officials. Lwampanga and Kakooge sub counties were selected to participate in the study. In each sub county two parishes were chosen and two villages were randomly selected in each parish to participate in the study. Twenty households in each village were randomly selected and interviewed raising a total of eighty respondents. Data was cleaned to ensure no missing values, entered into SPSS spreadsheet and analyzed using descriptive statistics (frequencies, means and percentages). 
Table 1. Rainfall and temperature indices with their definitions and units used in the study

\begin{tabular}{|c|c|c|c|}
\hline ID & Indicator name & Indicator definitions & Units \\
\hline PRCTOT & Annual total wet precipitation & Annual total precipitation from days $\geq 1 \mathrm{~mm}$ & $\mathrm{~mm}$ \\
\hline $\mathrm{R} 10 \mathrm{~mm}$ & Heavy precipitation days & Count of days when $\mathrm{RR}>10 \mathrm{~mm}$ & days \\
\hline CWD & Maximum length of wet spell & $\begin{array}{l}\text { Maximum number of days when precipitation } \geq \\
1 \mathrm{~mm}\end{array}$ & days \\
\hline CDD & Maximum length of dry spell & $\begin{array}{l}\text { Maximum number of consecutive dry days } \\
\text { when precipitation }<1 \mathrm{~mm}\end{array}$ & days \\
\hline TN90p & Warm nights & $\begin{array}{l}\text { Percentage of time when daily min temperature }> \\
\text { 90th percentile }\end{array}$ & $\%$ \\
\hline TX90p & Hot days & $\begin{array}{l}\text { Percentage of time when daily max temperature } \\
>90 \text { th percentile }\end{array}$ & $\%$ \\
\hline
\end{tabular}

\section{Results}

\subsection{Frequency of precipitation extremes}

Heavy precipitation days showed weak positive non-significant increasing trends $(\mathrm{P}>0.05)$. Heavy precipitation days were most frequent in 1981 and 1998 (Figure 2b). 1980 recorded the lowest frequency of heavy precipitation days. PRCTOT also showed non-significant increasing trend. 1981 recorded the highest total rainfall received at $2270.5 \mathrm{~mm}$ while the previous year 1980 recorded the least annual rainfall of about $1000 \mathrm{~mm}$. Consecutive wet days (CWDs) were declining at about 0.08\% (Figure 2c). Most wet spells were experienced in 1971, 1976, 1978 and 1988. Consecutive dry days (CDDs) revealed significant positive increasing trend $(\mathrm{P}<0.05)$ of about $0.8 \%$ annually (Figure 2d).
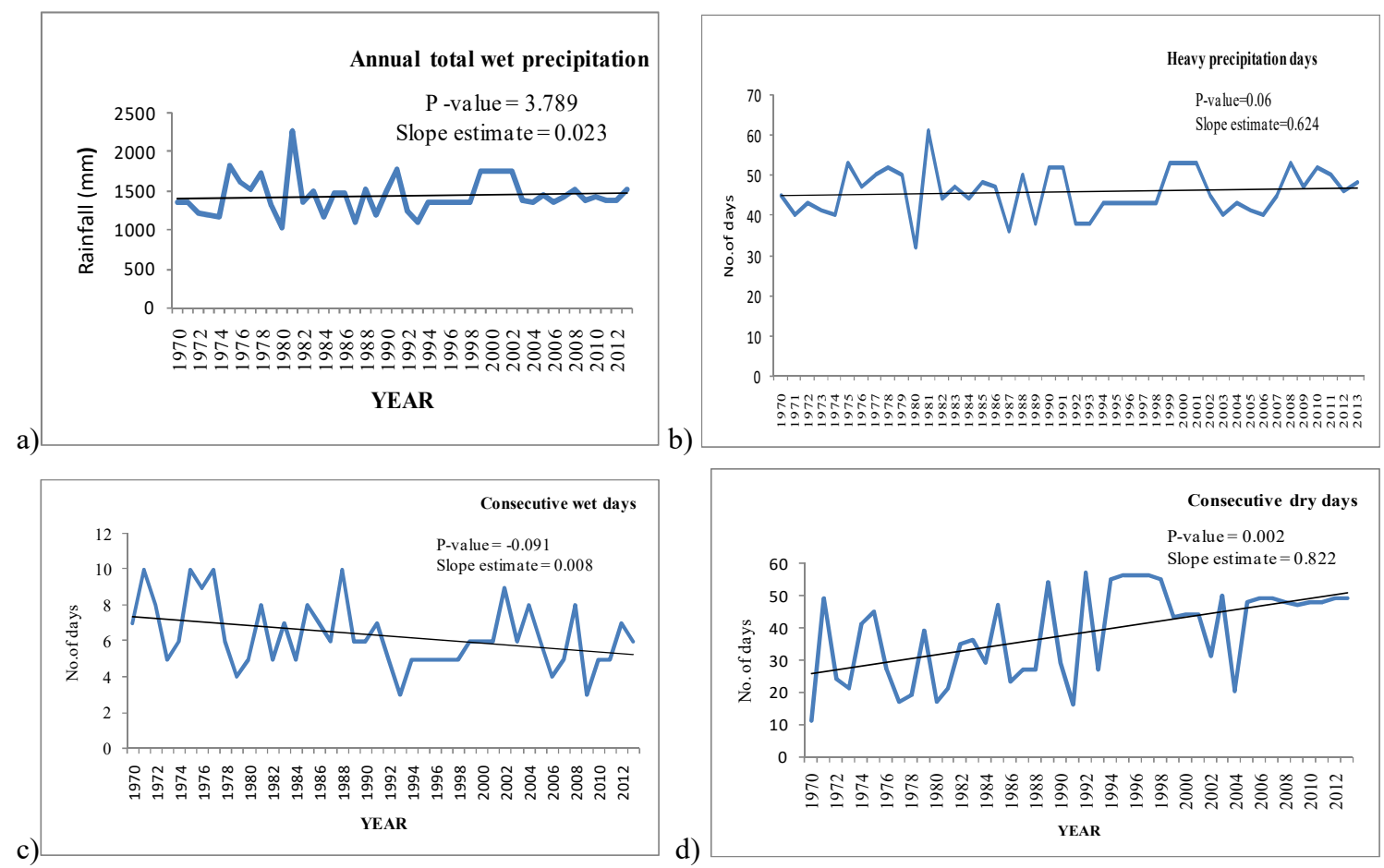

Figure 2 (a-d): Trends of precipitation extremes 


\subsection{Extreme hot days (TX90p) and warn nights (TN90p)}

Percentage of time where daily maximum temperature $\mathrm{Tx}>90^{\text {th }}$ percentile showed an increasing positive trend though not statistically significant $(\mathrm{P}>0.05)$. This indicates that Nakasongola district is increasingly becoming hotter. The highest frequency of extreme hot days were experienced in 1991. TN90p which measures count of days when daily minimum temperatures, $\mathrm{TN}>90^{\text {th }}$ percentile revealed non-sigficant declining trend (Figure 3 ). Warm nights were most experienced in 1975.

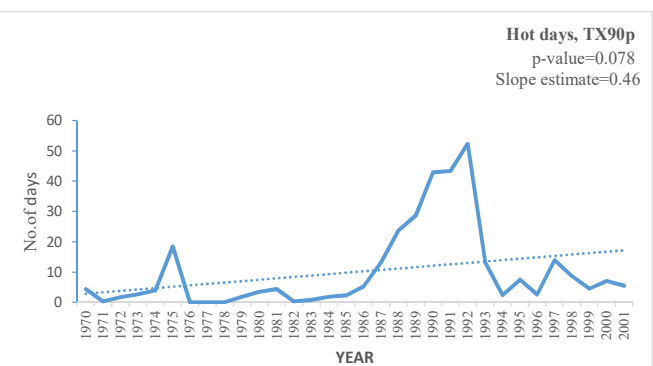

a)

Figure 3: Percentage hot days and warm nights

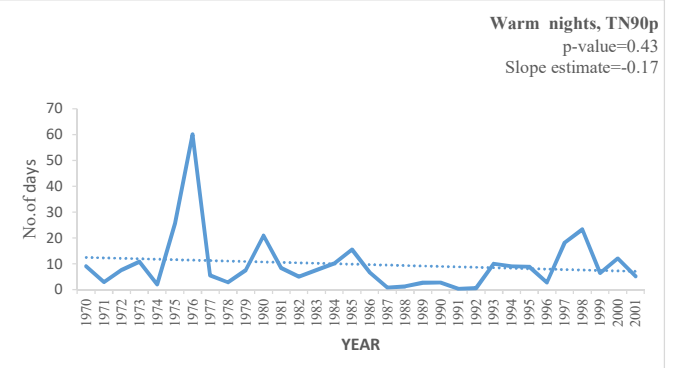

b)

\subsection{Farmers perceptions to changes in rainfall and temperatures extremes}

Majority of the respondents ( $86 \%$ ) reported decreasing amounts/frequency of extreme rainfall events (Figure 4). Ninety five percent revealed that both day and night temperatures were increasing. Farmers attributed changes in rainfall and temperatures to be as a result of poor farming practices like land/bush clearing, overgrazing, swamp reclamation, bush burning, deforestation and charcoal burning among others. However, $27 \%$ perceived changes in rainfall and temperature extremes to be of natural phenomenon perhaps due to God's wish (Table 2).

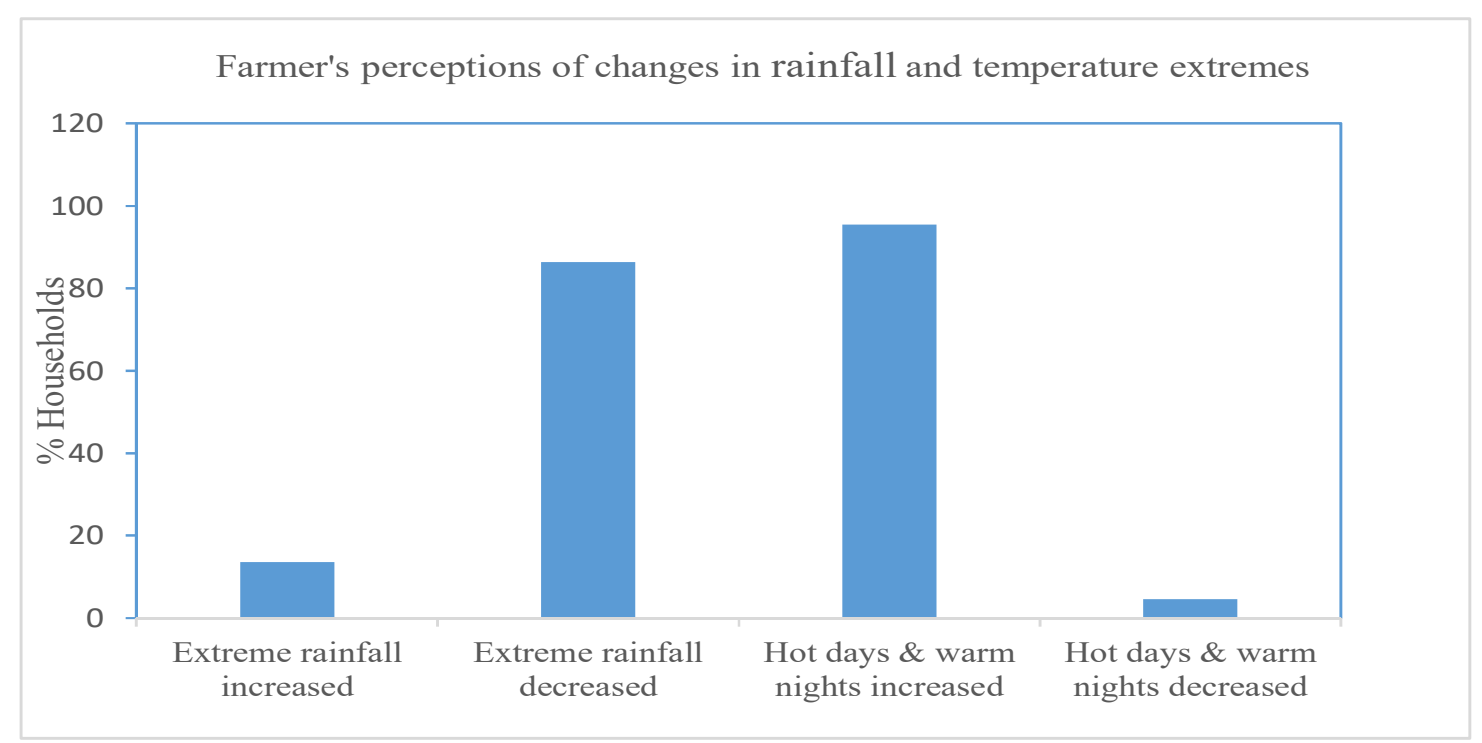

Figure 4: Response to changes in rainfall and temperature extremes over 30 years ago

\subsection{Occurance and severity of severe drought and floods events}

Most farmers reported that severe prolonged drought periods were experienced during 1980 and 1999 (Figure 5) while severe floods were highest during $1997 / 98$ and 1962 . In addition, $95 \%$ of the respondents reported that they were never warned prior before the occurrence of such extreme events. Consquently, majority of the households were not prepared and therefore lost property and assests ranging from crop fields to heads of cattle among others (Table 2). Severe droughts as reported by farmers could be a reflection of increasing consecutive dry days (Figure 1d). CDDs were the most perceived precipitation extreme event by farmers and perhaps this explains the importance of rainwater in sustaining livelihoods in the region. Farmers 
reported that increasing CDDs (drought periods) were the most responsible for lack of pastures and water for livestock in semi-arid Nakasongola. More than $50 \%$ of the households reported loss of cattle due to starvation as a result of lack of pastures (Table 2).

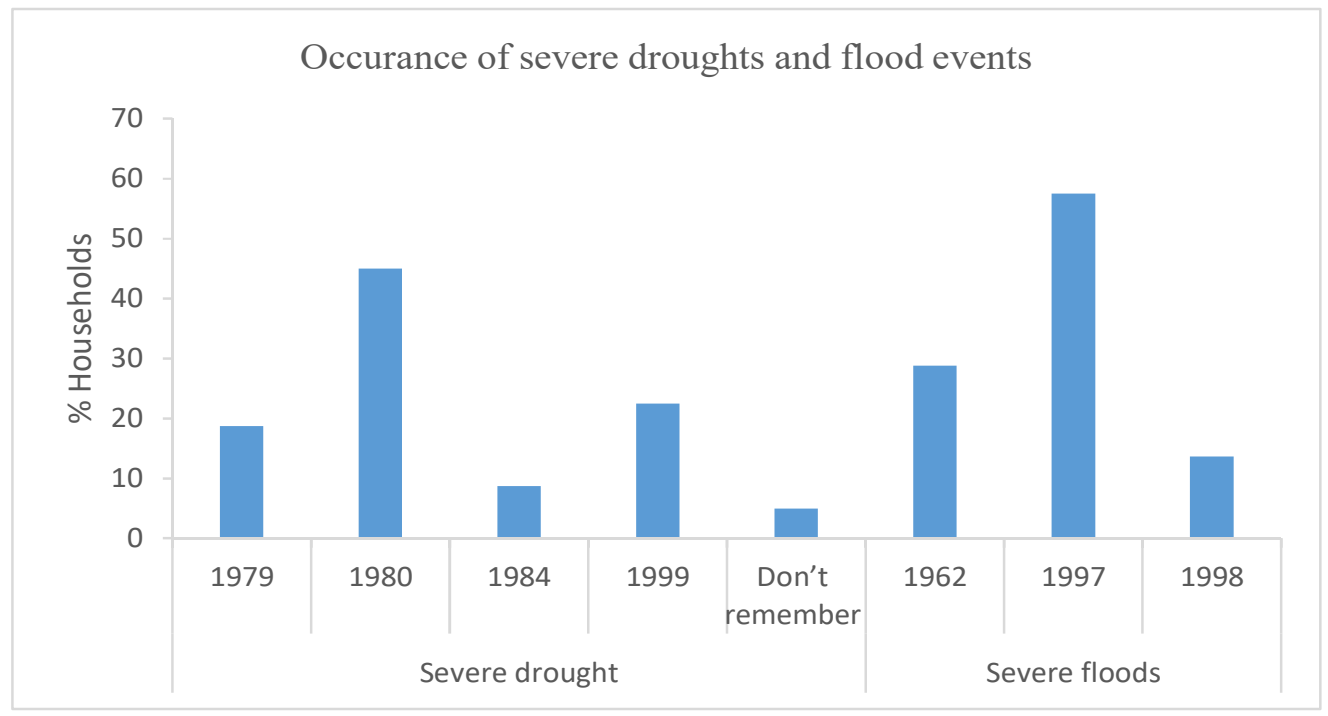

Figure 5: Frequency of severe drought and flood events

Table 2. Consquences of severe drought and flood events

\begin{tabular}{lc}
\hline Impacts of severe droughts & Percentage \\
\hline Total crop failure & 27.5 \\
$1-5$ heads of cattle & 37.5 \\
$>6$ heads of cattle & 13.8 \\
None & 21.2 \\
Major causes of rainfall and temperature extremes & \\
Natural/God's wish & 27.3 \\
Poor farming practices & 72.7 \\
Received early warning? & \\
Yes & 5.0 \\
No & 95.0 \\
\hline
\end{tabular}

\subsection{Drivers of feed and water scarcity}

Majority of the farmers reported scarcity of livestock feeds/pastures due to increasing droughts periods, invasive pasture weeds like Lantana camara and increased termite action among others (Table 4). Scarcity of water was as a result of number of factors which included; increased drought periods, lack of labour to source water from distant water sources, increased siltation of valley tanks due to soil erosion, inadequate water sources and increasing number of water users among others (Table 4). 
Table 4. Percentage response on key drivers of scarcity of pastures and water for livestock

\begin{tabular}{lc}
\hline Months of feed/pasture scarcity & 66.2 \\
January-March & 17.5 \\
April-June & 3.8 \\
July-September & 12.5 \\
October-December & \\
Causes of scarcity of pastures/feeds & 57.5 \\
Increased droughts & 3.8 \\
High stocking rates / livestock numbers & 8.7 \\
Small grazing area & 17.5 \\
Invasive pasture weeds & 12.5 \\
Termite action & \\
Causes of water scarcity & 10.0 \\
Inadequate water sources & 45.5 \\
Increased droughts/drying up of water sources & 17.5 \\
Lack of labour for fetching & 8.7 \\
Increasing livestock numbers & 12.0 \\
Siltation of water sources due to erosion & 6.3 \\
Contamination by livestock and humans & \\
\hline
\end{tabular}

\subsection{Coping/adaptation strategies}

Figure 4 shows coping/adaptation strategies households use during extreme events like severe droughts and floods. The most important strategies to overcome impacts of scarcity of pastures during severe drought periods included; fencing off grazing land, diversification of livestock species and control of stocking rates (Figure 4). Farmers who acknowledged conserving pastures in form of hay or silage were few indicating that conservation of forages for future use in severe dry spells was still very low. Fifty seven percent of the respondents reported diversifying livestock species and breeds as a strategy to spread risk in events of extreme scarcity of pastures for livestock. Farmers also reported changing grazing time for livestock especially cattle. For example farmers have learnt to allow grazing of livestock to begin as early as 4.00 a.m (04:00 hrs) when standing hay has got some dew and is still palatable for grazing cattle. Strategies to off-set water scarcity challenges included; water harvesting, migrating to wet riparian areas of permanent water sources like wetlands and lakes among others.

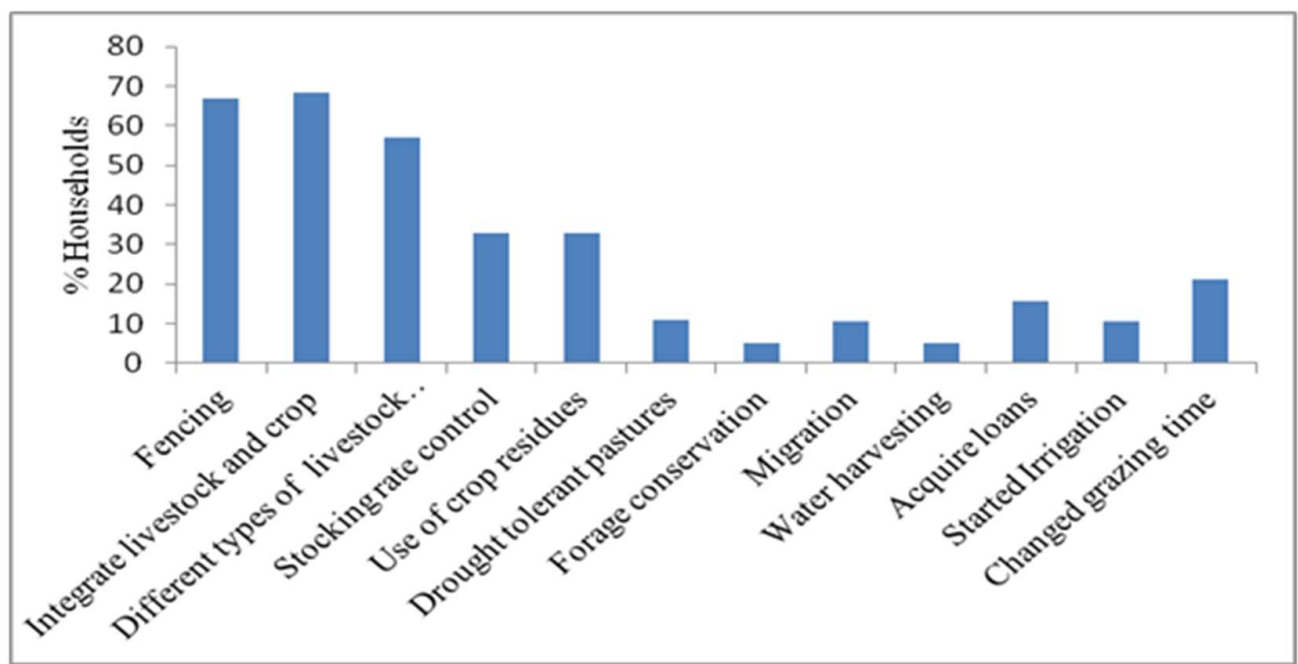

Figure 4. Farmers' coping/adaptation strategies 


\subsection{Barriers constraining adaptation strategies}

Failure to adapt was being influenced largely by insecure land ownership rights and lack of information concerning climatic events such as floods, dry spells, start and end of the rains (Figure 5). Twelve percent of the respondents cited lack of start- up investment funds to facilitate adaptation to extreme rainfall and temperature events. Twenty three percent of the respondents acknowledged failure to adapt citing lack of interest. Farmers who lacked interest perceived changes in extreme events as a result of natural phenomenon and further believed that such changes were short-lived.

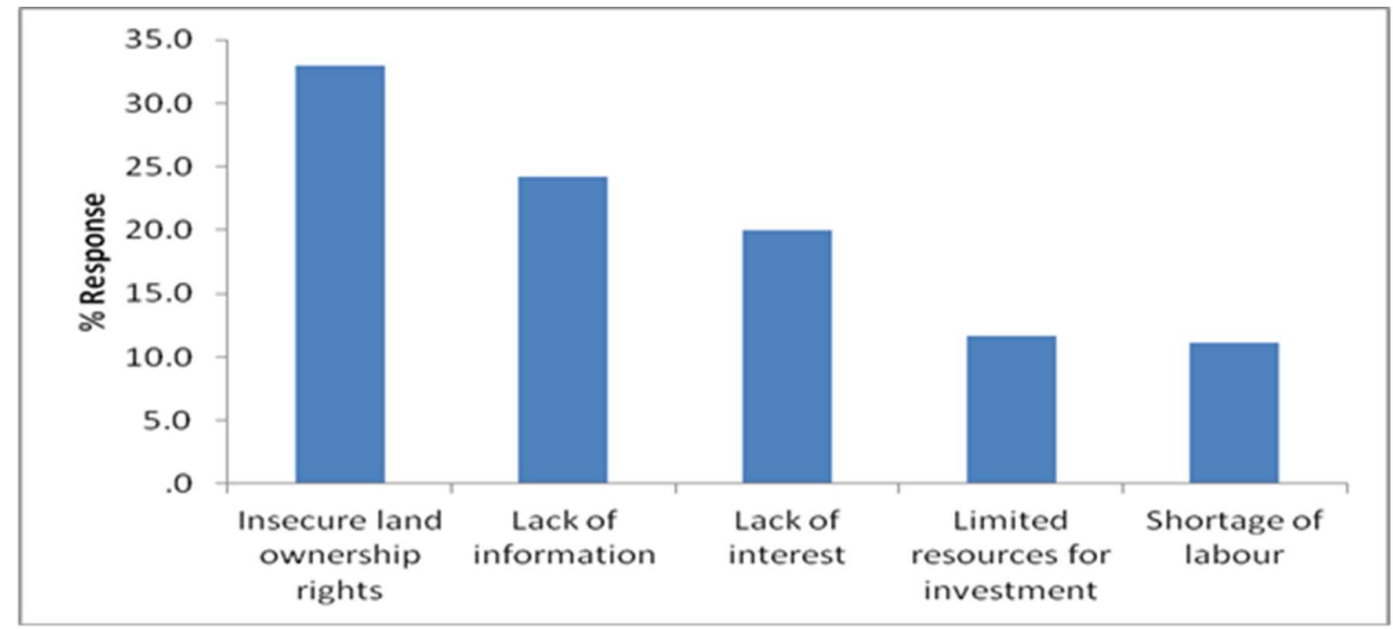

Figure 5. Barriers to adaptation strategies

\section{Discussion}

PRCPTOT index revealed weak increasing non significant trend $(\mathrm{P}>0.05)$ indicating that the total annual rainfall receipts were gradually increasing (Figure 2a). Heavy precipitation days were most frequent during 1980/81 and 1990/91 and were also steadily increasing though non-significant. These results are consistent with global trends of increasing precipitation extremes (Alexander et al. 2006). However, frequency of consecutive wet days (CWDs), were significantly reducing while CDDs showed strong significant increasing trends $(\mathrm{P}<0.05)$. These results are consistent with Nsubuga et al (2014) who reported that dry spells were increasing in Uganda. Results further indicated that the beginning of the 1990s decade marked a reduction in the frequency of CWDs while CDDs became more pronounced compared with the previous decades (1970s and 1980s). Frequency of extreme hot days and warm nights were also significantly increasing (Figure 3). New et al. (2006) reported similar findings in West Africa of increasing warming trends in temperature extremes. The warmest days and nights are increasing at a rate approximately comparable to the global average (Alexander et al., 2006; Aguilar, et al., 2009). These results also compare well with Basalirwa (1995), who also reported that the cattle corridor will most likely become drier. Similarly, majority of farmers acknowledged decreasing rainfall patterns (Table 2), changes in time for onset and cessation of the rains. Majority of the farmers recalled that severe drought periods were experienced in 1980 and 1999 which was in close agreement with the observed trends from climatological data. Farmers attributed changes in rainfall and temperature to be as a result of poor farming practices. Over $70 \%$ of the respondents cited poor farming practices especially cultivation, deforestation, bush burning during land preparation and charcoal making among others. Respondents who believed that changes in extreme rainfall and temperature extremes like severe droughts and floods were as a result of natural phenomenon were also evident. Decreasing rainfall coupled with increasing hot days and warm nights directly affect availability of pastures and surface water sources for watering livestock and domestic purposes. Topp and Doyle (1996), affirms that changes in rainfall are most likely to influence the quality and quantity of forage produced and consequently altering the productivity of grazing livestock. Occurrences of severe dry days are not a new phenomenon in Uganda for example Stampone et al. (2011), revealed that there was an increase in the occurrence of drought periods of which 1991-2000 decade recorded the highest frequency of droughts. Farmers also acknowledged that some pasture species like Hyparrhenia spp were disappearing while Lantana camara and Sporobolous spp invasive pasture weeds were becoming more abundant in the rangelands. 
Majority of the farmers were aware that climate extremes for example prolonged droughts and floods were becoming more frequent. However, most of the farmers reported that these changes were as a result of poor farming practices (Table 2) such as overgrazing, uncontrolled bush burning and destruction of woodlands for charcoal burning among others. Severe prolonged droughts consequently result into increased crop failure and shortage of water and pastures for livestock. Lack of water and pastures for livestock leads into reduced milk production and loss of body condition. Loss of livestock especially cattle as a result of extreme starvation were evident (Table 2). However, no household reported losing small stock like goats as a result of scarcity of feeds/natural browse. As noted by Busajja Livingstone aged 63 years one of the farmers from Nakalikinya village, Lwampanga subcounty; “...throughout my life time I have never seen a goat that died of starvation (lack of browse) it's only cattle especially those which are old that are vulnerable". Farmers' adaptation strategies in response to increasing extreme dry spells included: fencing of grazeable pastures/land, use of drought tolerant pasture species, control of stocking rates, utilization of crop residues and diversification of livestock species among others (Figure 4). Most farmers acknowledged fencing off grazing land as the key adaptation strategy to control stock and be able to practice rotational grazing which could guarantee availability of pastures for increased livestock production throughout the year. These results are consistent with Dixon et al. (2001) who reported that adaptation technologies that farmers adopt depend mostly on the type of crop or system involved. Other studies for example Deressa et al. (2009) reports soil conservation, tree planting early and late planting as adaptation strategies to climate change in Ethiopia. Sixty eight percent of the respondents acknowledged diversifying livestock species/ breeds among the key strategies used. Perhaps this can be explained by the fact that different livestock species have unique environmental stress levels and as such can cope differently in various agro-climatic conditions. By keeping different livestock species like goats and chicken farmers were able to spread the risk and guarantee production thus reducing the vulnerability of their individual households to extreme climatic events. Technological adaptation strategies /options such as forage conservation and feeding crop residues remain rarely used to offset dry season feeding challenges (Figure 4). Indeed, very few farmers acknowledged to have ever conserved pastures in form hay during the dry season. On the contrary, $11 \%$ of the farmers reported using drought tolerant pasture species (Figure 4) to ensure availability of pastures for livestock during the dry season. Elsewhere technological advancements like use of drought tolerant pasture species have proven an effective adaptation strategy to increasing frequency of dry spells (Kurukulasuriya and Rosenthal, 2003; Thornton et al. 2009). Therefore farmers should be encouraged to adopt drought tolerant pasture species in order to ensure availability of pastures for livestock throughout the year.

Although farmers appear to be aware of climate extremes and as such have developed adaptation strategies, quite often they encounter barriers which constrain adaptation. These included; insecure land ownership rights, lack of information concerning changes in extreme climatic events, shortage of labour and lack of start-up funds (Figure 5). These results compare well with Fosu-mensah et al. (2010) who reported that land tenure was among the most significant factors affecting adaptive capacity of farmers in Ghana. In addition Shultz et al. (1997) urges that land tenure is vital for adaptation as land owners tend to adopt new technologies quickly than tenants. Traditionally, most of the land in the cattle corridor was owned communally (Kisamba Mugerwa, 2001). However, the communal land ownership system is slowly changing into private individual ownership with increased individual rights to land. However, this transition comes with a number of challenges since most of the farmers still perceive land ownership to be communal. For example farmers acknowledged that it's almost impossible to fence off grazing land to ensure quality pastures for livestock and in addition plant drought tolerant pastures species when land is owned by the entire community or landlord. Farmers further revealed that fencing off communal land in most cases is interpreted as land theft and can attract attention from the public and criminal charges preferred to the concerned individuals/persons for trespassing. Studies conducted elsewhere for example in Ethiopia, have reported that farmers who encountered barriers such as lack of information and shortage of labour among others usually fail to adapt to climate change (Deressa et al. 2009). Despite the fact that farmers are aware of climate extremes, it was evident that there is hardly any early warning information system which further complicates the process of adaptation. The study showed that only less than $5 \%$ of the households had ever received some information alerting them of possible occurrence of rainfall extremes like floods. Moreover lack of information concerning climate extremes when they are most probable to occur and ways to overcome them was reported among the barriers farmers encounter. Therefore policy should aim at increasing farmers' access to early warning climatic information while streamlining individual land ownership rights in existing communal land tenure systems to facilitate adaptation to climate change. 


\section{Conclusion}

It was evident from the study that farmers are aware of changes in rainfall and temperature extremes. Farmers perceived changes in rainfall and temperature extremes compared well with observed climatological trends. CDDs and heavy precipitation days were the most perceived extremes indices because of the associated impacts especially shortage of pastures and water or prevalence of floods which reduce livestock productivity. Increased drought periods and invasive pasture weeds were the most perceived causes of scarcity of pastures while drying up and siltation of water sources like valley tanks were the most drivers of water scarcity thus resulting into a decline in livestock productivity. Key coping/adaptation strategies included; fencing of grazeable land, integration of livestock and crop production, diversification of livestock species and breeds, control of stocking rates, water harvesting, and use of drought tolerant pasture species, utilization of crop residues, water harvesting, changing grazing time and acquiring agricultural loans as investment capital among others. Limited access to climate information and insecure rights to land ownership were key barriers constraining adaptation to increasing climate extremes in the region. Therefore policies that can promote and ensure secure individual land ownership rights coupled with control of invasive pasture weeds and protection of water sources from degradation while improving farmers' access to early warning climate information can effectively facilitate adaptation to climate change.

\section{Acknowledgements}

The authors are very grateful to German Academic Exchange Service (DAAD) and International Livestock Research Institute (ILRI) for funding the study. Special thanks to the National Meteorological Authority, Ministry of Water and Environment for availing rainfall and temperature data sets.

\section{References}

Alex, N., K. Jesse and N. Neoline. (2019). Evaluation of past and future extreme rainfall characteristics over Eastern Uganda. Journal of Environmental \& Agricultural Sciences. 18:38-49

Alexander, L.V., X. Zhang, T.C.Peterson, J. Caesar, B.Gleason, A.M.G Klein Tank, M.HaylockD.Collins, B. Trewin, F.Rahimzadeh, A. Tagipour, K.Rupa Kumar, J.Revadekar, G.Griffiths, L.Vicent, D.B. Stephenson, J.Burn, E.Anguilar, M.Brunet, M.Taylor, M. New, P. Zhai, Rusticucci, M. \& VazquezAnguirre, J.L. (2006). Global observed changes in daily climate extremes of temperature and precipitation. Journal of Geophysical Research, 111, D05109.

Anguilar, E. A.Aziz Barry, M. Brunet, L.Ekang, A.Fernandes, M. Massoukina, J.Mbah, A.Mhanda, D.J. do Nascimento, T.C. Peterson, O. Thamba Umba, Tomou, M \& Zhang, X. (2009). Changes in temperature and precipitation extremes in western central Africa, Guinea Conakry, and Zimbabwe, 1955-2006. Journal of Geophysical research, 114, D02115.

Basalirwa, C.P.K. (1995). Delineation of Uganda into climatological rainfall zones using principal component analysis. International Journal of Climatology 15:1161-1177.

Beddington, J., Asaduzzaman M. Fernandez A. Clark, M. Guillou, M. Jahn, M. Erda, L. Mamo, T. Van Bo, N Nobre, CA Scholes, Sharma, R \& Wakhungu, J. (2011). Achieving food security in the face of climate change: Summary for policy makers from the Commission on Sustainable Agriculture and Climate Change. CGIAR Research Program on Climate Change, Agriculture and Food Security (CCAFS). Copenhagen, Denmark.

Burton, I., Malone, E.L. \& Huq, S. (2005). Adaptation policy Frameworks for climate change. Developing strategies, Policies and Measures. Cambridge University Press, Cambridge.

CCSP (Climate Change Science Program). 2008. Weather and Climate Extremes in a Changing Climate. Regions of Focus: North America, Hawaii, Caribbean, and U.S. Pacific Islands. A Report by the U.S. Climate Change Science Program and the Subcommittee on Global Change Research. [Thomas R. Karl, Gerald A. Meehl, Christopher D. Miller, Susan J. Hassol, Anne M. Waple and William L. Murray (eds.)]. Department of Commerce, NOAA's National Climatic Data Center, Washington, D.C., USA, 164 pp.

Deressa, T.T., R. M. Hassan, C. Ringler, Alemu, T. \&Yusuf, M. (2009). Determinants of farmers' choice of adaptation methods to climate change in the Nile Basin of Ethiopia. Global Environ. Change (2009), doi:10.1016/j.gloenvcha.2009.01.002

Dixon, J., Gulliver, A. \& Gibbon, D. (2001). Farming systems and poverty: Improving Farmers' livelihoods in a changing World. FAO (Food and Agriculture Organisation), Rome, and World Bank, Washington, DC.

Donat M. G. \& L. V. Alexander., 2012. The shifting probability distribution of global daytime and night-time temperatures, Geophysical Research Letters, 39, L14707, 5 doi:10.1029 /2012GL052459. 
Donat M. G.; L. V. Alexander, H. Yang, I. Durre, R. Vose, R. J. H. Dunn, K. M. Willett, E. Aguilar, M. Brunet, J. Caesar, B. Hewitson, C. Jack, A. M. G. Klein Tank, A. C. Kruger, J. Marengo, T. C. Peterson, M. Renom, C. Oria Rojas, M. Rusticucci, J. Salinger, A. S. Elrayah,S. S. Sekele, A. K. Srivastava,B. Trewin,C. Villarroel, L. A. Vincent, P. Zhai, Zhang, X. \& S. Kitching,S. (2013). Updated analyses of temperature and precipitation extreme indices since the beginning of the twentieth century: The HadEX2 dataset, J. Geophys. Res. Atmos., 118, doi:10.1002/jgrd.50150

Fosu-mensah, B., Vlek, P.L.G. \& Manschadi, A. M. (2010). Farmers' perception and adaptation to climate change. A case study of Dekyedumase district in Ghana. World food system-A contribution from Europe.

IPCC (Intergovernmental Panel on Climate change).2001. Climate change 2001: Impacts, adaptation, and vulnerability, J. J. McCarthy, et al., eds. Contribution of Working Group II to the Third Assessment Report of the Intergovernmental Panel on Climate Change. Cambridge, UK: Cambridge University Press.

IPCC (Intergovernmental Panel on Climate change).2007. Climate Change 2007: Impacts, adaptation and vulnerability. Contribution of Working Group II to the Fourth Assessment Report of the Intergovernmental Panel on Climate Change, M.L. Parry, O.F. Canziani, J.P. Palutikof, P.J. van der Linden and C.E. Hanson, eds.

KCCA (Kampala Climate Change Action). (2015). Energy and Climate Profile. Kampala, Uganda

Kisamba-Mugerwa, W. 2001. Rangelands management policy in Uganda. A Paper prepared for the International Conference on Policy and Institutional Options for the Management of Rangelands in dry Areas May 7 11, 2001 (Hammamet, Tunisia).

Kurukulasuriya, P \& Rosenthal, S. 2003. Climate change and agriculture: a review of impacts and adaptations. Climate change series paper No.91. World Bank, Washington, DC.

Majaliwa, J.G.M., M.M. Tenywa, D. Bamanya, W. Majugu, P. Isabirye, C. Nandozi, J. Nampijja, P. Musinguzi, A. Nimusiima and Luswata, K.C. (2015). Characterization of historical seasonal and annual rainfall and temperature trends in selected climatological homogeneous rainfall zones of Uganda. Global J. Sci. Front. Res. 15(4):21-40.

Manton, M.J., P.M. Della-Marta, M.R. Haylock, K.J. Hennessy, N. Nicholls, L.E. Chambers, D.A. Collins, G. Daw, A. Finet, D. Gunawan, K. Inape, H. Isobe, T.S. Kestin, P. Lefale,C.H. Leyu, T. Lwin, L. Maitrepierre, N. Ouprasitwong, C.M. Page, J. Pahalad, N. Plummer, M.J. Salinger, R. Suppiah, V.L. Tran, B. Trewin, Tibig, I. \& Yee, D. (2000). Trends in extreme daily rainfall and temperature in Southeast Asia and the south pacific: 1961-1998. Int. J. Climatolology. DOI: 10.1002:joc.610.

MLWE (Ministry of Lands, Water and Environment). 2003, "Water Sector Reform: Water for Production Component - Water for Production Strategy 2003 - 2015".

Mpairwe, D., Mugerwa, S., Mutetikka, D., Kiwuwa, G., Zziwa, E., Owoyesigire, B. \& Peden, D. (2008). Options to improve livestock-water productivity (LWP) in the cattle corridor within the White Nile sub-basin in Uganda. Paper presented in the "Challenge Programme on Water and Food" International Conference held $10^{\text {th }}-15^{\text {th }}$ November 2008, Addis Ababa, Ethiopia.

Nakasongola District State of Environment Report (2004). Nakasongola District Council, http://www.nemaug.org.

NEMA (National Environmental Management Authority). 2008. National State of Environment Report for Uganda, 2008, National Environmental Management Authority, Kampala p.282

New, M., B. Hewitson, D.B. Stephenson, A. Tsiga, A. Kruger, A. Manhique, B.Gomez, Caio A. S. Coelho, D. Ntiki Masisi, E. Kululanga, E.Mbambalala, F. Adesina, H. Saleh, J. Kanyanga, J. Adosi, L. Bulane, L. Fortunata, M. L. Mdoka, \& Robert Lajoie. (2006). Evidence of trends in daily climate extremes over southern and West Africa, Journal of Geophysical Research, 111, D14102, doi:10.1029/2005JD006289.

Nsubuga, F. W. N., Olwoch, J. M and Rautenbach C.J.deW. (2014). Variability properties of daily and monthly observed near surface temperatures in Uganda; 1960-2008” International Journal of Climatology, Vol.34 pp 303-314

Owoyesigire, B., D. Mpairwe, P. Ericksen and D. Peden. 2016. Trends and variability of extreme rainfall and temperature in the cattle corridor of Uganda. Uganda Journal of Agricultural Sciences, 17 (2): 231 244pp.

Peterson, T.C., X.Zhang, M. Brunet-India, \& J. L.Vazquez-Anguirre. (2008). Changes in North America extremes derived from daily weather data. Journal of Geophysical Research, 113,D07113,doi:10.1029/20007JD009453

Shultz, S., Faustino, J., \& Melgar, D. (1997). Agroforestry and Soil Conservation: Adoption and Profitability in El Salvador. Agroforestry Today, 9, 16-17. 
Sridharan, V., E.P. Ramos, E. Zepeda, B. Boehlert, A. Shivakumar, C. Taliotis and M. Howells. (2019). The Impact of Climate Change on Crop Production in Uganda-An Integrated Systems Assessment with Water and Energy Implications. Water 2019, 11, 1805.

Stampone, D. M., Hartter, J. Chapman, A. C. \& Ryan, J.S. (2011). Trends and Variability in Localized Precipitation Around Kibale National Park, Uganda, Africa. Research Journal of Environment and Earth Sciences, 3(1): 14-23.

Thornton, P.K.; R.B. Boone, K. A. Galvin, S.B. Burnsilver, M.M. Waithaka, J. Kuyiah, S.Karanja, E. GonzalezEstrada \& Herrero, M. (2007). Coping Strategies in Livestock -dependent Households in East and South Africa: A synthesis of four case studies. Springer journal of Human ecology (2007) 35: 461-476. DOI 10.1007/s10745-007-9118-5

Thornton, P.K, P.G. Jones, T.Owiyo, R.L Kruska, M.Herrero, V. Orindi, S. Bhadwal, P. Kristjanson, A. Notenbaert, N. Bekele \& Omolo, A. (2008). Climate change and Poverty in Africa. Mapping hotspots of vulnerability. AfJARE. Volume 2 No 1 March 2008.

Thornton, P.K, J.van de Steeg, A. Notenbaert \& Herrero, M. (2009). The impacts of climate change on livestock and livestock systems in developing countries: A review of what we know and what we need to know. Global Environ. Change (2009), doi:10.1016/j.gloenvcha.2009.05.002

Topp, C.F.E. \& Doyle, C.J. (1996). Simulating the impact of global warming on milk and forage production in Scotland: 2. The effects on milk yields and grazing management of dairy herds. Agricultural Systems 52 (2/3), 243-270.

Wang, X. L. \& Feng, Y. (2009). RHtestsV3 User Manual. Climate Research Division, Science and Technology Branch, Environment Canada. 26 pp.

Zhang, X \& Feng,Y. (2004). RclimDex User manual. Climate Research Division, Science and technology Branch, Environment Canada. 23pp. 